1990

\title{
The Corporate Personality in American Law: A Summary Review
}

Phillip Blumberg

University of Connecticut School of Law

Follow this and additional works at: https://opencommons.uconn.edu/law_papers

Part of the Business Organizations Law Commons, Constitutional Law Commons, and the Jurisprudence Commons

\section{Recommended Citation}

Blumberg, Phillip, "The Corporate Personality in American Law: A Summary Review" (1990). Faculty Articles and Papers. 197. https://opencommons.uconn.edu/law_papers/197 


\section{HEINONLINE}

Citation: 38 Am. J. Comp. L. Supp. 491990

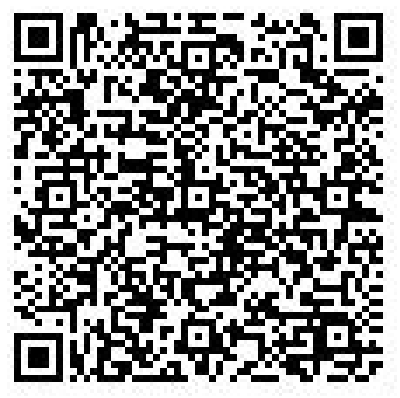

Content downloaded/printed from

HeinOnline (http://heinonline.org)

Mon Aug 15 16:46:51 2016

-- Your use of this HeinOnline PDF indicates your acceptance of HeinOnline's Terms and Conditions of the license agreement available at http://heinonline.org/HOL/License

-- The search text of this PDF is generated from uncorrected OCR text.

-- To obtain permission to use this article beyond the scope of your HeinOnline license, please use:

https://www.copyright.com/ccc/basicSearch.do?

\&operation $=$ go\&search $T y p e=0$

\&lastSearch $=$ simple\&all=on\&titleOrStdNo=0002-919X 
TOPIC I.B.2.

\section{PHILLIP I. BLUMBERG}

\section{The Corporate Personality in American Law: A Summary Review}

\section{Traditional Theories of the Nature of the Corporate PERSONALITY}

Although recognition of the separate legal personality of the corporation with existence as a juridical entity, separate from its shareholders, goes back centuries, there has been worldwide controversy as to the exact nature of the corporation as a legal institution. In the United States, this development has gone through three stages and is now entering a fourth.

First, in the early days of the Republic, the courts saw the corporation as an "artificial person" in the terms expressed by the English authorities, Coke and Blackstone. ${ }^{1}$ As Chief Justice Marshall put it:

A corporation is an artificial being, invisible, intangible, and existing only in contemplation of law. Being the mere creature of law, it possesses only those properties which the charter of its creation confers upon it, either expressly or as incidental to its very existence."2

The corporation was a creation of the legislature with certain "core" rights including the capacity to sue and be sued, the capacity to hold and transfer property, and to have perpetual existence, irrespective of any change in its shareholders. This view has been alternatively called the artificial person, or fiction, or concession, or grant doctrine.

As the Supreme Court commenced determination of the rights of the corporation under the new federal Constitution, a second,

Phillip I. Blumberg is Dean of the School of Law, and Professor of Law and Business Emeritus, The University of Connecticut School of Law.

Copyright, The Blumberg Trust.

1. See E. Coke, First Part of the Institute of the Law of England or a Commentary on Littleton 6, 412 (1628); 2 id. at 250a; Case of Sutton's Hospital, 10 Coke 23a; 77 Eng. Rep. 960, 970-71 (1612) (the corporation is "invisible, immortal, and rests only in the intendment and consideration of the law"); $1 \mathrm{~W}$. Blackstone, Commentaries on the Laws of England 470 (1st ed. 1765). (1819).

2. See Trustees of Dartmouth College v. Woodward, 17 U.S. (4 Wheat.) 518, 636 
more complex theory of the corporate personality emerged reflecting the interests of the incorporators and shareholders of the corporation. The corporation was perceived as an association of individuals contracting with each other in organizing the corporation, with its core attributes as an artificial legal person supplemented by the attribution to it of constitutional rights of its shareholders. As Justice Field said in The Railroad Tax Cases:

Private corporations are, it is true, artificial persons but ... they consist of aggregations of individuals united for some legitimate purpose ... It would be a most singular result if a constitutional provision intended for the protection of every person against partial or discriminatory legislation by the states should cease to exert such protection the moment the person becomes a member of the corporation ... The courts will always look beyond the name of the artificial being to the individuals whom it represents. ${ }^{3}$

This conception of the corporation has alternatively been called the associational, or aggregate, or contract theory.

The essential feature of the artificial person theory was its emphasis on the central role of state action. The supplemental "associational" theory was reenforced by the growth of general incorporation statutes in the nineteenth century making corporate status freely available ${ }^{4}$ and moving the predominant role in corporate organization from the state to the incorporators.

Third, the corporation has been perceived as an organic social reality with an existence independent of, and constituting something more than, its changing shareholders. This has been termed the natural entity or real entity or realism theory. Under this view, the corporation is a juridical unit with its own claims, much like those of a natural person, that extend beyond both the circumstances of its legal creation by the state and the claims or interests of its shareholders. It is the ultimate stage of the entity view or the "strong entity" view.

As Professor Teubner points out, each of the competing contentions involved in the "old dispute on the nature of corporate personality have some validity and contributes to a better understanding of

3. See The Railroad Tax Cases, 13 F. 722, 744 (C.C.D. Cal. 1882), appeal dismissed as moot sub nom. San Mateo County v. Southern Pac. R.R., 116 U.S. 138 (1885).

4. New York enacted the first general incorporation statute as early as 1811; this was the first in the world. N.Y. Act of Mar. 22, 1811, ch. 67. However, general incorporation did not become the norm until the 1870s. See W. Hurst, The Legitimacy of the Business Corporation 37 (1970). 
the full dimensions of a "remarkably fluctuating reality."5 The corporation is indeed simultaneously a legal fiction, a contractual network, and a "real" organization.

A remarkable amount of scholarly examination of these theories has continued for more than a century. After decades of debate, the growth of the "legal realism" movement" during the 1920s led to increasing recognition that, whatever its philosophical nature, the corporation was a "means to achieve an economic purpose"7 and that the fundamental issue was not one of theoretical concept but the adaptation of the law to achieve an appropriate degree of control over the activities of the corporation in the light of the values of the times.

For half a century thereafter, the intensity of interest in the problem of corporate personality ebbed. Then with the great increase in the utilization of economics as a tool for examination of legal institutions, libertarian scholars arguing for increased reliance on market forces reopened the debate. Perceiving the corporation in associational terms as a complex network of various contracting parties, $^{8}$ they sought to justify reduced governmental intervention in economic matters by emphasizing the role of shareholders as contracting parties in organizing the corporation ${ }^{9}$ and reasserting the associational view.

The three traditional theories have much more than philosophical interest. They have helped shape the law. The view of the corporation as an "artificial person" underlies entity law, the view of the corporation with rights and duties separate from those of its shareholders, for ages past the prevailing view of Western jurisprudence. Arising from historical and philosophical roots, this ancient doctrine, which preceded the triumph of limited liability by centuries, has been tremendously re-enforced by it. ${ }^{10}$ Entity law provides

5. See Teubner, "Enterprise Corporatism: New Industrial Policy and the 'Essence' of the Legal Person," 36 Am. J. Comp. L. 130, 130-33, 138 (1988).

6. See L. Kalman, Legal Realism at Yale, 1927-60 ch. 1 (1986).

7. See Tanaka, J., dissenting in Barcelona Traction, Light \& Power Co., (1970) I.C.J. 3, 131-32. See also Bijur, J. in Farmers' Loan \& Trust Co. v. Pierson, 130 Misc. $110,119,222$ N.Y.S. 532, 543 (Sup. Ct. 1927) ("more nearly a method than a thing"), quoted in H. Henn and J. Alexander, Laws of Corporations 147 (3d ed. 1983); Dewey, "The Historic Background of Corporate Legal Personality," 35 Yale L.J. 655 (1926).

8. See, e.g., Alchian and Demsetz, "Production, Information Costs and Economic Organization," $62 \mathrm{Am}$. Econ. Rev. 777 (1972); Jensen and Meckling, "Theory of the Firm: Managerial Behavior, Agency Costs and Ownership Structures," 3 Fin. Econ. 305 (1976); Fama, "Agency Problems and the Theory of the Firm," $88 \mathrm{~J}$. Pol. Econ. 288 (1980). See also Bratton, "The 'Nexus of Contract' Cooperation: A Critical Appraisal," 74 Corn. L.Q. 407 (1989).

9. See R. Hessen, In Defense of the Corporation chs. 1, 2 (1979); R. Winter, Government and the Corporation (1978).

10. See Blumberg, "Limited Liability and Corporate Groups," 11 J. Corp. L. 573, 577 et seq. (1986). 
the substratum on which Anglo-American corporation law rests.

The view of the corporation as an association or aggregate of the individuals composing it played an important role in the late nineteenth century in facilitating the development of the law to broaden and extend constitutional protections to corporations in order to protect the economic interests of shareholders. It survives today in some areas of the law regulating in internal corporate affairs. Even where adopted, however, it has been used to support the attribution of shareholders' interests to the corporation for assertion by the corporation not by shareholders. ${ }^{11}$ Moreover, it has had no influence whatsoever in issues involving the imposition of liability or other duties on shareholders. Thus, notwithstanding any philosophical inconsistency, the doctrine has not led to any abandonment of entity law or lack of full recognition of the corporation as a separate juridical unit.

The third stage, or the corporation as a "real entity," is the view that has dominated corporation law for decades. It is especially evident in the attribution to corporations of constitutional rights similar to those of natural persons in most cases.

American law is now entering a fourth stage. With the increasing role in the society of large corporations typically operating as multi-tiered multinational groups of parent and subsidiary corporations, the "real entity" view is being supplemented by increasing efforts of statutory and common law in selected areas to deal with corporate groups as an entity and to impose group obligations and less frequently to recognize group rights as well. In this movement still in its early stages, yet another theory of the corporation is beginning to emerge.

In some areas of American law, particularly statutory law, traditional theories of the corporate personality are being increasingly supplemented by a newer doctrine emphasizing enterprise over entity. This theory of the corporate enterprise or corporate group as the legal unit, while still inchoate, is particularly evident in such concepts as the "control" standard in many federal regulatory and tax statutes, the "unitary business" doctrine in state tax and constitutional law, the "integrated enterprise" theory in labor relations law, and in modern developments in "piercing the veil jurisprudence" which I have termed the law of corporate groups. ${ }^{12}$

11. Chief Justice Taney, among others, recognized that the associational theory was theoretically inconsistent with the concept of limited liability. See Bank of Augusta v. Earle, 38 U.S. (5 Pet.) 519, 586 (1839).

12. See P. Blumberg, The Law of Corporate Groups: Procedural Problems of Parent and Subsidiary Corporations (1983); P. Blumberg, The Law of Corporate Groups: Problems in the Bankruptcy or Reorganization of Parent and Subsidiary Corporations, Including the Law of Corporate Guaranties (1985); P. Blumberg, The 


\section{The Corporate Personality in the Courts}

\section{A. Constitutional Applications}

Although the traditional English concept of the separate legal personality of the corporation had been firmly embraced by the United States after the Revolution, this meant only that the corporation was a separate legal entity with fundamental core rights. Entity law provided no answer to the uncertainties of the application of the new Constitution to corporations. In determining the extent to which corporations could invoke constitutional provisions and obtain constitutional rights in addition to their unchallenged core rights at common law, the courts inevitably turned to theories of the corporate personality.

The new Republic knew little about corporations. At the time of adoption of the Constitution, there were very few corporations. As late as 1801 , there were only 317 corporations in the entire country. ${ }^{13}$ These were almost entirely in banking, insurance, and public service areas; only a handful were manufacturing corporations. Determining constitutional meaning with respect to a class of parties with which neither the society nor the law had had much experience rendered the problem of constitutional construction even more difficult.

The language of the Constitution further complicated the problem. Thus, the Constitution does not uniformly describe the parties it protects. In different provisions, it refers to "citizens," "people," or "person." Other provisions generally prohibit certain acts by the federal government without reference to the class protected. Did these terms include corporations?

\section{1. "Citizen"}

a. Diversity of Citizenship Jurisdiction: Article III

The first corporate constitutional controversy arose in connection with the diversity-of-citizenship jurisdiction of the federal courts. Article III, Section 2, Clause 1 of the Constitution provides that the federal judicial system may hear "cases" or "controversies" involving "citizens" of different states. ${ }^{14}$ This was clear enough in

Law of Corporate Groups: Tort, Contract, and Other Common Law Problems in the Substantive Law of Parent and Subsidiary Corporations (1987); P. Blumberg, The Law of Corporate Groups: Problems of Parent and Subsidiary Corporations under Statutory Law of General Application (1989). The fifth volume dealing with statutory law directly applicable to parent and subsidiary corporations being written with Professor Kurt A. Strasser is expected to appear in 1992.

13. See 2 J. Davis, Essays in the Earlier History of American Corporations, Number 4, Eighteenth Century Business Corporations in the United States 27 (1917) (reissued 1965); W. Hupst, The Legitimacy of the Business Corporations 14 (1970).

14. See McGovney, "A Supreme Court Fiction: Corporations in the Diverse Citi- 
the case of natural persons, but what of corporations? Was a corporation a "citizen" for purposes of this provision?15

Unless a corporation was a "citizen" or otherwise treated as a "citizen," diversity of citizenship could not arise, and the federal courts would be barred from all litigation involving corporate parties, whether as plaintiff or defendant, insofar as common law and corporation law matters were concerned. ${ }^{16}$ The scope of the new federal judicial power over major areas of law affecting the new corporate society was at stake.

This question arose in 1809 in Bank of the United States $v$. Deveaux, ${ }^{17}$ in which a corporate action on a note was brought in the federal courts under diversity-of-citizenship jurisdiction. Chief Justice Marshall, writing for a unanimous court, first described the corporation in language borrowed from the English law as a "mere creature of the law, invisible, intangible, and incorporeal." He then agreed that a corporation, "that invisible, intangible, and artificial being, that mere legal entity is certainly not a citizen." Nevertheless, he upheld the action. He held that for purposes of determining jurisdiction, the case was controlled by the citizenship of its shareholders. He stated that the "controversy is, in fact and in law, between those persons [the shareholders] suing in their corporate character, by their corporate name, for a corporate right" and the other party. The term "citizen" is only used "to describe the real persons who come into court, in this case, under their corporate name."18

The rationale of the decision in Bank of the United States $v$. Deveaux is one of the earliest judicial expressions of the associational view of the corporation. Chief Justice Marshall made it plain that the associational view was superimposed upon, rather than replacing, entity law. Thus, he carefully referred to the corporation as a "mere creature of the law," "an artificial being" and "a mere legal entity" and emphasize that the case involved the assertion in "corporate name" of a "corporate right."19 Shareholder interests served only to support the attribution to corporate entities of access to the

zenship Jurisdiction of the Federal Courts," 56 Harv. L. Rev. 853 (1943) (hereinafter cited as McGovney).

15. In the case of natural persons, citizenship was determined by residence, a doctrine later confirmed in the Fourteenth Amendment. See U.S. Const. amend. XIV.

16. Such matters not involving federal constitutional or statutory questions or admiralty matters may only be heard in the federal courts under diversity jurisdiction.

17. 9 U.S. (5 Cranch) 61 (1809).

18. 9 U.S. (5 Cranch) at $86,88,91$.

19. 9 U.S. (5 Cranch) at 87. 
federal courts and the assertion of federal jurisdiction over corporate litigation in the event of diversity.

Decades later in Louisville, Cincinnati \& Charleston Railroad $v$. Letson, ${ }^{20}$ decided in 1844 and Marshall v. Baltimore \& Ohio R.R., ${ }^{21}$ decided in 1855, the Court abandoned this technique of looking through corporate parties to the citizenship of their shareholders. While recognizing that a corporation was not a "citizen" for this purpose, it, nevertheless, continued to preserve the "valuable privilege" of federal jurisdiction for corporations. The Court held that irrespective of the actual citizenship of shareholders, it would be conclusively presumed that the shareholders of a corporation were citizens of the state of incorporation.

\section{b. Privileges and/or Immunities: Article Four and Fourteenth Amendment}

"Citizens" is also the crucial term in Article IV, Section 2, providing that "The Citizens of each State shall be entitled to all the privileges and Immunities of Citizens in the several States" and in the Fourteenth Amendment, Section 1 providing that "No State shall make or enforce any law which shall abridge the privileges or immunities of citizens of the United States." (emphasis added) In a series of cases, the Court consistently held that corporations were not "citizens" for these purposes and refused to apply Article IV and the Fourteenth Amendment to invalidate state statutes discriminating against foreign corporations.

Writing for the Court in Bank of Augusta $v$. Earle, ${ }^{22}$ decided in 1839, Chief Justice Taney relied entirely on entity law and the "artificial person" theory. Pointedly refusing to apply the associational theory, he stated: "Whenever a corporation makes a contract, it is the contract of the legal entity; of the artificial being created by the charter; and not the contract of the individual members." 23 He concluded that a corporation was "a mere creature" of local law without any "legal existence out of the boundaries of the sovereignty by which it was created." Unlike Deveaux, the Court refused to look to

20. 43 U.S. (2 How.) 497 (1844).

In Letson, the Court rejected the Deveaux standard and reverted to the artificial person view of the corporation. The Court had that for purposes of diversity jurisdiction, a corporation was to be regarded as a "person, though an artificial one, inhabiting and belonging to" the state of incorporation and therefore "entitled, for the purpose of suing and being sued, to be deemed a citizen of that state." 43 U.S. (2 How.) at 555. The holding in Letson that a corporation was a "citizen" was controversial and did not long survive. In Marshall, decided nine years later, the Court found it prudent to retreat in theory, but not in result.

21. Marshall v. Baltimore \& Ohio R.R., 57 U.S. (16 How.) 314, 327-29 (1853).

22. 38 U.S. (13 Pet.) 519 (1839).

23. 38 U.S. (13 Pet.) at 587. 
the shareholders and outlaw such discrimination as a means of protecting shareholder rights. Chief Justice Taney made plain his concern with the implications with respect to limited liability of shareholders that could arise from a contrary decision resting on the associational theory. ${ }^{24}$

In Paul v. Virginia, ${ }^{25}$ decided in 1868 under Article Four, and in Pembina Consolidated Silver Mining and Milling Co. v. Pennsylvania, ${ }^{26}$ decided in 1888 under the Fourteenth Amendment, the Court held that corporations were not "citizens" for purposes of these provisions. Justice Field stated:

[T]he 'term citizens . . . applies only to natural persons, members of the body politic owing allegiance to the State, not to artificial persons created by the legislature, and possessing only such attributes as the legislature has prescribed. ${ }^{27}$

Conceptually, the different conclusions on the two constitutional references to "citizen[s]" are manifestly inconsistent. However, as a matter of constitutional development, opening the federal courts to litigation involving corporations is a very different issue than permitting states to exclude foreign corporations in matters not involving interstate commerce. The fact that the same constitutional term, "citizen" was employed did not prevent conflicting conclusions on its applicability to corporations. The Court reached its differing results by drawing a distinction between natural persons with recognized personal rights and artificial persons, to wit: corporations, lacking such rights.

\section{2. "Person"}

The term "person" is the crucial term in no less than four constitutional provisions: the Equal Protection and the Due Process Clauses of the Fourteenth Amendment and the Self Incrimination and the Double Jeopardy Clauses of the Fifth Amendment. The Court has held that corporations are protected persons under the Equal Protection, Due Process, and Double Jeopardy Clauses, but are not protected under the Self Incrimination Clause.

24. 38 U.S. (13 Pet.) at 587. However, judicial use of the associational theory did not lead to any threat to the political acceptance of limited liability. See Blumberg, "Limited Liability and Corporate Groups," $11 J$. Corp. L. 573, 587-95 (1986).

25. 75 U.S. (8 Wall.) 168 (1868).

26. 125 U.S. 181 (1888). Article IV refers to "Citizens of each State" while the Fourteenth Amendment refers to "citizens of the United States." Although Pembina did not focus on this distinction, the Court subsequently seized on the distinction to make the provision the "all but forgotten clause of the Constitution." Slaughter House Cases, 83 U.S. (16 Wall.) 36 (1872). See Colgate v. Harvey, 296 U.S. 404, 443 (1935) (Stone, J., dissenting).

27. 75 U.S. (8 Wall.) at 177. 
a. Equal Protection of the Laws: Fourteenth Amendment

The status of the corporation under the Equal Protection Clause of the Fourteenth Amendment referring to "person" first arose before the Supreme Court in Santa Clara County v. Southern Pacific Railroad decided in 1886.28 Although the question had been argued at length in the various briefs, the Court surprisingly announced:

The court does not wish to hear [oral] argument on the question whether the provision in the Fourteenth Amendment to the Constitution, which forbids a State to deny to any person within its jurisdiction the equal protection of the laws applies to corporations. We are all of the opinion that it does."

The Court's brief announcement threw no light on the rationale for the conclusion. ${ }^{29}$

\section{b. Due Process of Law: Fourteenth Amendment}

Pembina Consolidated Silver Mining and Milling Co. v. Pennsylvania followed two years after Santa Clara. The Court held that a corporation - while not a "citizen" for purposes of the Privileges or Immunities Clause of the Fourteenth Amendment as noted above - was a "person" within the meaning of the Due Process and Equal Protection Clauses of the Amendment. The Court held: "Under the designation of person [in the Amendment] there is no doubt that a private corporation is included. Such corporations are merely associations of individuals united for a special purpose and permitted to do business under a particular name and have a succession of members without dissolution."30

\section{118 U.S. 394, 396 (1886).}

Santa Clara and the constitutional protection of corporations as "person[s]" under the Fourteenth Amendment has given risen to much academic discussion. For some of the more recent literature, see, e.g., Flynn, "The Jurisprudence of Corporate Personhood: The Misuse of a Legal Concept" in Corporations and Society: Power and Responsibility 131 (W. Samuels and A. Miller eds. 1987); Horwitz, "Santa Clara Revisited: The Development of Corporate Theory," 88 W. Va. L. Rev. 175 (1985) (hereinafter cited as Horwitz); Hovenkamp, "The Classical Corporation in American Legal Thought," 76 Geo. L. J. 1593, 1597-1601, 1640-51 (1988); Schane, "The Corporation Is a Person: The Language of a Legal Fiction," 61 Tulane L. Rev. 563 (1987) (hereinafter called Schane.); Hager, "Bodies Politic: The Progressive History of Organizational 'Real Entity' Theory," 50 U. Pitt. L. Rev. 575 (1989). Comment, "The Personification of the Business Corporation in American Law," 54 U. Chi. L. Rev. 1441 (1987) (hereinafter cited as Comment, Personification of the Corporation); Note, "Constitutional Rights of the Corporate Person," 91 Yale L.J. 1641 (1982).

29. It is far from clear what the Court meant by its statement. See Comment, Personification of the Corporation, supra note 28 , at 1464 n.64.

30. 125 U.S. 181, 189 (1888). The description of the corporation is borrowed from Justice Story's concurring opinion in the Dartmouth College case, 17 U.S. (4 Wheat.) 518,666 (1819). 
Pembina does not make it clear what kind of "person" the corporation was in qualifying under the "persons" protected by the provision. Apparently not ready to conclude that corporations artificial persons that they were - generally qualified as "persons" for purposes of the Fourteenth Amendment, the Court found it necessary to invoke the associational theory asserting that "corporations are merely associations of individuals."

The Court soon took the final step. In Covington \& Lexington Turnpike Road Co. v. Sandford, ${ }^{31}$ decided in 1896, and in Southern Railway $v$. Greene ${ }^{32}$ decided in 1910, the Court felt able to say that it is "now settled" and "no longer open to question" that "corporations are persons within the meaning of the constitutional provisions forbidding the deprivation of property without due process of law, as well as denial of the equal protection of the laws." Southern Railway represents the great divide. There, the Court went on to quote the sentence in Pembina referring to the corporation as a "person" for purpose of the constitutional provisions while pointedly omitting from the quotation the very next sentence referring to corporations as "merely associations of individuals." 33 By so doing, the Court showed that for the first time, it was prepared to rely solely on an entity view treating the corporation as a "person" without any distinction between "artificial" and "natural" persons. The associational theory was no longer required to support the attribution of constitutional rights to the corporate entity.

The Court had at last moved beyond both the artificial person view in its pure form, or in its reenforced form involving reliance on both the artificial person and the associational theories. It had emerged with a new "strong entity" theory. In this more developed concept, the corporation was for the first time explicitly recognized as a "real" entity or person, qualifying with isolated exceptions ${ }^{34}$ for the same rights as natural persons under the constitutional protection of the provision. In the process, the Court had emerged with a doctrine under which all forms of business organizations - whether sole proprietorship, partnership, or corporations - received very much the same constitutional protection.

31. 164 U.S. 578, 592 (1896). In Sandford, the Court relied on Santa Clara, Pembina, and two other decisions in which Justice Field had written the opinion.

32. 216 U.S. 400 (1910).

33. 216 U.S. at 412-13. The fuller quotation from Pembina appears in the text accompanying note 30 supra.

34. Corporations are not "citizens" for purposes of the Privilege and Immunities Clauses of Article Four and the Fourteenth Amendment nor are they "person[s]" for purposes of the Self Incrimination Clause of the Fifth Amendment. Whether a corporation is a "person" under the provisions of the Due Process Clause pertaining to "liberty" as distinct from "property" is still not clear. Compare Northwestern Life Ins. Co. v. Riggs, 203 U.S. 243, 255 (1906) with First National Bank v. Bellotti, 435 U.S. 765 (1978). Nor is the full extent of a corporation's right of free speech settled. 
c. Self Incrimination: Fifth Amendment

In contrast to its decisions construing "person" in the Equal Protection and Due Process Clauses to incluce "corporations," the Court held in Hale v. Henkel, decided in 1906, that corporations were not protected by the Self Incrimination Clause of the Fifth Amendment providing: "nor shall [any person] be compelled in any criminal case to be a witness against himself . . . ."35

Justice Brown relied on the artificial person theory and on the power of the states over the corporations created by them. $\mathrm{He}$ stated:

... the corporation is a creature of the State. It is presumed to be incorporated for the benefit of the public ... It would be a strange anomaly to hold that a State, having chartered a corporation to make use of certain franchises, could not in the exercise of its sovereignty inquire how these franchises had been employed, and whether they had been abused and demand the production of the corporate books and papers for that purpose. ${ }^{36}$

This markedly contrasts with Justice Brown's utilization of the associational theory to apply the Unreasonable Searches and Seizures Clause of the Fourth Amendment to a corporation in the very same case, as discussed infra.

\section{d. Double Jeopardy: Fifth Amendment}

The Fifth Amendment provides: "nor shall any person be subject for the same offence to be twice put in jeopardy of life or limb ...." Notwithstanding the inescapable reference to natural persons in the use of such terms as "life or limb," the Court, without expressly deciding the issue, has repeatedly assumed the applicability of the clause to corporations. ${ }^{37}$ Relying on such sub silentio holdings, the lower federal courts have expressly held that corporations are protected by the provision. ${ }^{38}$

The different conclusions on the applicability to corporations of

35. 201 U.S. 43 (1906). Numerous subsequent cases have reaffirmed the inapplicability of the Self Incrimination Clause to corporations. E.g., Wilson v. United States, 221 U.S. 361 (1911); Bellis v. United States, 417 U.S. 852 (1974); Essgee Co. v. United States, 262 U.S. 151 (1923).

36. 201 U.S. at 74-75.

37. E.g., United States v. Martin Linen Supply Co., 430 U.S. 564 (1977); American Tobacco Co. v. United States, 328 U.S. 781 (1946). See Note, "Double Jeopardy and Corporations: 'Lurking in the Record' and 'Ripe for Decision,'" 28 Stan. L. Rev. 805 (1976).

38. E.g., United States v. Hospital Monteflores, Inc., 575 F.2d 332 (1st Cir. 1978); United States v. Security Nat'l Bank, 546 F.2d 492 (2d Cir. 1970), cert. denied, 430 U.S. 950 (1977). See Blumberg, The Law of Corporate Groups: General Statutory Law, supra note 12 , at $\S 3.06$. 
the Fifth Amendment Clauses pertaining to Self Incrimination and Double Jeopardy are particularly interesting as a textual matter. Both clauses use the same term "person." In addition, the Self Incrimination Clause follows immediately after the Double Jeopardy Clause in the text of the Fifth Amendment, and, indeed, is grammatically part of the prior clause, sharing with it the same subject, "person."

Further, the decisions applying the Double Jeopardy clause to corporations are inconsistent with the decisions refusing to protect corporations under the Self Incrimination clause. The associational theory provides no explanation of the different construction of the two companion clauses. Nor may one contend that the existence of corporate injury damaging to shareholders from risk of trial and conviction justifies invocation of the Double Jeopardy clause. ${ }^{39}$ The very same factors are insufficient to result in application of the Self Incrimination clause.

\section{3. "The People"}

a. Unreasonable Searches and Seizures: Fourth Amendment

Hale $v$. Henkel not only involved the applicability to corporations of the constitutional protection to "person[s]" against self incrimination in the Fifth Amendment, as discussed above. It also involved the applicability of the protection granted to "the people" against unreasonable searches and seizures in the Fourth Amendment. ${ }^{40}$ The Court in Hale v. Henkel ${ }^{41}$ held that the term "people" protected corporations against the production of corporate records seized under circumstances violating the provision.

Justice Brown relied on the associational theory, ${ }^{42}$ asserting: "A corporation, is, after all, but an association of individuals under an assumed name and with a distinct legal entity. In organizing itself as a collective body, it [the association of individuals] waives no constitutional immunities appropriate to such body." 43

This invocation of the associational theory contrasts with Justice Brown's refusal to look beyond the artificial person view in re-

39. See, e.g., United States v. Armco Steel Corp., 252 F. Supp. 364, 368 (S.D. Cal. 1966).

40. The Fourth Amendment provides: "The right of the people to be secure in their persons, houses, papers and effects, against unreasonable searches and seizures, shall not be violated." U.S. Const. amend. IV.

41. 201 U.S. 43 (1906).

42. The Court also emphasized the importance of the economic interests at stake. In further support of its result, the Court stated: "Corporations are a necessary feature of modern business activity and their aggregated capital has become the source of nearly all great enterprises." 201 U.S. at 76.

43. 201 U.S. at 76. 
fusing to protect corporations under the Self Incrimination Clause in the very same case.

It is evident that the different results in Hale $v$. Henkel do not turn on the different terminology employed: "people" in the Fourth Amendment and "person" in the Fifth. The Court perhaps refused to protect corporations under the Self Incrimination clause because such an action in no way clashed with or eroded the personal claims of shareholders to be protected under the clause. By contrast, the Court could more readily uphold the applicability of the Unreasonable Search and Seizures clause because the rights of shareholders against search and seizure could be attributed to the corporation under the associational theory.

\section{General Constitutional Prohibitions on Governmental Power}

The Supreme Court has considered the applicability to corporations of two constitutional provisions imposing general limitations on governmental action: the prohibitions against impairment of contracts and abridging freedom of speech or press.

\section{a. Impairment of Contracts: Article I}

Article I, Section 10[1], Clause 5 provides: No State shall . . . pass any . . . law impairing the obligation of contract." The celebrated Dartmouth College case, ${ }^{44}$ decided in 1819 , involved a challenge to the constitutionality of a New Hampshire statute changing the governance structure of the College from that provided in the original charter. While the Court affirmed the traditional view of the corporation as an "artificial being" or "person" created by the state, it concluded that the corporate charter was not simply a state grant or concession but was also a contract between the state and the incorporators, ${ }^{45}$ and the amendatory statute was an unconstitutional impairment of the contract in violation of Article I. As in Deveaux, decided ten years earlier, the Court, after affirming the continued vitality of entity law in determining the fundamental nature of the corporate personality, again embraced the associational view to expand the boundaries of corporate constitutional rights. ${ }^{46}$

44. Trustees of Dartmouth College v. Woodward, 17 U.S. (4 Wheat.) $518,642-44$ (1819).

45. 17 U.S. (4 Wheat.) at 642-44. See also Providence Bank v. Billings, 29 U.S. (4 Pet.) 514, 560 (1830) (Marshall, C.J.) ("... it is not denied, that a charter incorporating a bank is a contract.").

46. This appears plainly in Justice Story's concurring opinion: "An aggregate corporation .... is a collection of individuals united into one collective body, under a special name, and possessing certain immunities, privileges, and capacities in its collective character, which do not belong to the natural persons composing it." 17 U.S. (4 Wheat.) at 667 . 
b. Freedom of Speech: First Amendment

The First Amendment, Clause 2 provides: "Congress shall make no law . . . abridging the freedom of speech, or of the press." This prohibition restrains such action by the states as well; the Court has held that the Due Process Clause in the Fourteenth Amendment binding the states incorporates the First Amendment. ${ }^{47}$

In First National Bank v. Bellotti ${ }^{48}$ decided in 1978, the Court held by a five-to-four vote that a Massachusetts statute restricting corporate political expenditures to influence public referenda or issues, except on matters materially affecting the corporation, was unconstitutional because it violated the guaranty of free speech of the First Amendment.

Writing for a bare majority of the Court, Justice Powell did not find it necessary to articulate his own theory of the nature of the corporation in order to dispose of the case. Instead, he relied on the fundamental value of "the right of public discussion" from the societal point of view ${ }^{49}$ and held that a corporation could not be constitutionally barred from discussion of public issues. The four dissenters would have upheld the statute in reliance on the artificial person theory; they concluded that the corporation was only a creature of the state possessing only those rights granted it by the State. ${ }^{50}$ Justice Powell characterized this contention as "extreme."11

\section{Terminology or Nature of Interest}

In the light of the Court's inconsistent applications to corporations of constitutional provisions, it should be apparent that the decisions are not controlled by the terminology employed. Similarly, the inconsistent utilization of conflicting theories of corporate personality indicates that the theories are utilized to support results, rather than as guiding principles to help reach them.

As Justice Powell stated in First National Bank v. Bellotti: "Whether or not a particular [constitutional] guarantee is 'purely personal' [that is, available only to natural persons] or is unavailable for corporations for some other reason depends on the nature, history, and purpose of the particular constitutional provision." 52 "[N]ature, history, and purpose" control. Constitutional terminology

47. See Fiske v. Kansas, 274 U.S. 380 (1927); Near v. Minnesota, 283 U.S. 697

(1931); L. Tribe, American Constitutional Law § 11-2 (1988).

48. 435 U.S. 765 (1978).

49. 435 U.S. at 778 n.14, $783,792$.

50. 435 U.S. at 809 (Rehnquist, C.J.); 435 U.S. at 824 (White, J.).

51. However, in CTS Corp. v. Dynamics Corp. of America, 107 S.Ct. 1637, 1649

(1987), Justice Powell surprisingly relied on this very passage.

52. First Nat'l Bank v. Bellotti, 435 U.S. 765, 768-69, 778 n.14 (1978). 
and theories of the corporate personality - while not unimportant and utilized to justify the result - are not decisive.

\section{B. State Corporation Law}

When we turn from constitutional litigation to other areas of the law, we find many references to traditional entity law in the decisions insulating shareholders from responsibility for corporate actions $^{53}$ but relative little discussion of the nature of the corporate personality. This should be no surprise since the discussion of corporate personality to date has been concerned with the attribution of rights not the imposition of duties.

The associational theory of the corporation may be seen in the older common law insistence on unanimous stockholder approval for certain fundamental corporate changes, such as the merger or dissolution or sale of all, or substantially all, the assets of the business. These events are perceived as departures from the contract among shareholders underlying the foundation of the corporation and therefore, require the consent of all contracting parties. ${ }^{54}$ While this requirement for unanimity has vanished from most statutes, some vestiges of the "contract" principle remain to this day. Such examples include the doctrine of "waste,"55 and elimination of preferred stock dividend arrearages by charter amendment.56 It should be noted, however, that each of these matters relates to the internal governance of the corporation and to the allocation of corporate decisionmaking authority between the directors and the shareholders. None involves the corporation's dealings with the larger world.

\section{C. "Piercing the Veil Jurisprudence"}

Inevitably, the doctrine of each corporation as a separate and distinct entity with its own obligations for which its shareholders had no liability led in some cases to results that, however concep-

53. See P. Blumberg, The Law of Corporate Groups: Substantive Common Law, supra note 12 , at $\mathrm{ch} .6$.

54. See, e.g., Mason v. Pewabic Mining Co., 133 U.S. 50, 59 (1890); State ex rel. Brown v. Bailey, 16 Ind. 46 (1861); McCray v. Junction R.R., 9 Ind. 358 (1857); Abbott v. American Hard Rubber Co., 33 Barb. 578 (N.Y. 1861); Stevens v. Rutland \& Burlington R.R., 29 Vt. 545 (1851), collected in Horwitz, supra note 28, at $200 \mathrm{n}$. 128. See also V. Morawetz, $A$ Treatise on the Law of Private Corporations iii (2d ed. 1886).

55. See A.L.I., Principles of Corporate Governance $\$ 1.34$ (Tent. Draft No. 5, 1986) ("A transaction constitutes a 'waste of corporate assets' if its terms are such that no person of ordinary sound business judgment would say that the consideration received by the corporation was a fair exchange for what was received by the corporation").

56. See Keller v. Wilsor \& Co., 21 Del. Ch. 318, 190 A. 115 (1936) (statutory power authorizing shareholder amendment of charters did not permit amendment cancelling preferred stock accrued unpaid dividends) (subsequently overruled by statute). 
tually sound under the doctrines of entity law and limited liability, were unacceptable to the courts in the particular case before them. The law required a safety valve. The doctrine of "piercing" or "lifting" the veil, or disregard of entity in "exceptional" cases, first emerged in cases involving controlled corporations and controlling individual shareholders and were subsequently automatically applied to cases involving corporate groups as well.57 The cases adapting "piercing the veil jurisprudence" to corporate groups constitute the raw material out of which American enterprise law or a law of corporate groups is beginning to emerge out of episodic, incremental judicial decisions. ${ }^{58}$

In a growing number of areas, the application of "piercing the veil jurisprudence" to constituent companies of corporate groups is beginning to emerge as a form of enterprise law. Although these cases do not as yet reflect a well-defined body of law, they represent the early stages of the development of a law of corporate groups.

Such cases combine "control," particularly intrusive exercise of control over the decisionmaking processes of a subsidiary, with five very different elements to establish a foundation for disregard of the corporate entity: (a) lack of indicia of separate corporate organization such as separate offices, telephone numbers, stationery, plants, employees, or equipment; (b) lack of compliance with corporate formalities, such as failure to hold meetings of directors and shareholders, absence of minutes of meetings, lack of records, books of account, tax returns or reports; (c) lack of adequate capitalization commensurate to the risks and scale of the enterprise being undertaken; (d) group integration (economic integration, administrative interdependence, and financial interdependence); and (e) use of a common group public persona. ${ }^{59}$

Even where such factors have been shown, however, most, but not all, courts applying "piercing the veil jurisprudence" in common law cases still require additional proof of some "inequitable" or "morally culpable" or "fundamentally unfair" conduct of the parent corporation (or controlling shareholder) prejudicing creditors before the court will disregard the separate entity to impose liability or attribute other legal consequences to the parent or other affiliated corporations. ${ }^{60}$

Such disregard of entity of a constituent company of a corporate

57. See Blumberg, "Limited Liability and Corporate Groups," $11 J$. Corp. L. 574, 605-11 (1986).

58. This development is reviewed in the author's volumes in the series constituting The Law of Corporate Groups to which readers are referred. See supra note 12.

59. See P. Blumberg, The Law of Corporate Groups: Substantive Common Law, supra note 12 , at chs. $6,10-11,19-20$.

60. See, id., at $\S \S 9.02,9.03,18.01,18.02$. 
group and recognition of the corporate group as the relevant juridical unit for imposition of liability through "piercing the veil" occurs only in "rare" or "exceptional" cases. Courts exercise their powers of equitable intervention to prevent unacceptable conduct in particularly egregious cases. To establish a more satisfactory level of social control over multinational groups and their constituent companies, enterprise law would have to reach the normal, not the exceptional, aspects of multinational conduct. It would have to rest on the economic reality of the integrated operations of the constituents of the controlled group without regard to the existence of particular occasions of "inequitable" or other "morally culpable" conduct.

There are some signs the law is moving in this direction. In the area of American statutory law in particular, the "piercing the veil" decisions are increasingly recognizing that the stringent requirements of the traditional doctrine must be significantly relaxed in order to implement statutory objectives and prevent evasion or frustration of the statutory program. ${ }^{61}$

\section{D. "Unitary Business"}

The "unitary business" doctrine in U.S. constitutional law provides still another example of a judicial doctrine employing concepts of enterprise law. ${ }^{62}$ The doctrine provides a workable standard for determination of liability on constituent companies of corporate groups in the area of state taxation.

In five decisions from 1980 to 1983,63 the Supreme Court developed the theory of the "unitary business" as the standard for determining the constitutionality of the taxation by states of local affiliates of multinational enterprises by apportionment formulae taking into account the worldwide activities of the group of which the local affiliate was a constituent part.

Combining such factors as "control," economic integration and centralized managerial structure, the Court stressed that "the un-

61. See P. Blumberg, The Law of Corporate Groups: General Statutory Law, supra note 12, at $\S$ 2.05.3. See also, e.g., United States v. Advance Mach. Co., 547 F. Supp. 1085 (D. Minn. 1982); United Paperworkers Int'l Union v. Penntech Papers, Inc., 439 F. Supp. 610, 620-21 (D. Me. 1977), aff'd sub nom. United Paperworkers Int'l Union v. T.P. Property Corp., 583 F.2d 33 (1st Cir. 1978).

62. See P. Blumberg, The Law of Corporate Groups: General Statutory Law, supra note 12 , at $\S 4.08$.

63. Mobil Oil Corp. v. Commissioner of Taxes, 445 U.S. 425 (1980); Exxon Corp. v. Wisconsin Dep't of Revenue, 447 U.S. 207 (1980); ASARCO, Inc. v. Idaho State Tax Comm'n, 458 U.S. 307 (1982); F.W. Woolworth Co. v. Taxation \& Revenue Dep't, 458 U.S. 454 (1982); Container Corp. v. Franchise Tax Bd., 463 U.S. 159, reh'g denied, 464 U.S. 909 (1983). 
derlying economic realities of a unitary business" are decisive ${ }^{64}$ and refused to recognize formal distinctions between entities in the group corporate structure. In its analysis, the Court emphasized such factors as economies of scale, centralized management, and functional integration. The test is the existence of a "highly integrated business which benefits from an umbrella of centralized management and controlled interaction." 65

\section{The Corporate Personality in Regulatory Statutes}

The early American statutes regulating the business economy, such as the transportation acts, utilized entity law and suffered decades of ineffectiveness in dealing with railroad systems organized as corporate groups. With this unhappy experience before the Congress, major regulatory statutes commencing with the wave of reform in the New Deal period after 1933 instead frequently relied on principles of enterprise law utilizing the standard of "control." A more complex doctrine combining "control" with other factors has been utilized in the labor relations and employment discrimination area. The federal tax laws have for decades incorporated enterprise principles for particular sections of the Internal Revenue Code although the standards turning on "control" vary remarkably from section to section.

\section{A. "Control"}

In numerous American statutes, ${ }^{66}$ the standard of "control" extends the scope of the statutory regulatory program beyond the corporation conducting the regulated activity in question to other members of the corporate group of which it is a constituent. A common reference extends the statutory reach beyond the corporation conducting the regulated activity to "any corporation controlling it, controlled by it, or under common control."67 "Control" has been employed to transform the statutory scope from entity law to enterprise law and to sweep under the enactment an entire corporate group whenever any constituent company is subject to its provisions. For such purposes, some statutes set forth rebuttable presumptions

64. Mobil Oil Corp. v. Commissioner of Taxes, 445 U.S. 425, 440-41 (1980).

65. Exxon Corp. v. Wisconsin Dep't of Revenue, 447 U.S. 207, 224 (1980).

66. Such statutes include the Securities Act of 1933, 15 U.S.C. $\S 77 a$ (1982); Se- . curities Exchange Act of 1934, 15 U.S.C. $§ 78$ a (1982); Federal Communications Act of 1934, 47 U.S.C. $\S 219$ (a) (1982); Interstate Commerce Act, 49 U.S.C. $\S 310$ (1982); Federal Power Act, 16 U.S.C. $\$ 825 \mathrm{c}$ (1982); Internal Revenue Code 26 U.S.C. $\S \S 246 \mathrm{~A}, 267,269,304,368(\mathrm{c})$, 582(b), 957, 1504(a)(2), 1551(b), 1563.

67. E.g., 15 U.S.C. $\$ 77 \mathrm{~b}(3)$, (11) (1982) (Securities Act of 1933); 47 U.S.C. $\S 152(\mathrm{~b})(2)(1982)$ (Federal Communications Act of 1933). 
of "control" arising from voting power over 10 percent" 68 or 25 percent of the voting shares.69 The Internal Revenue Code uses benchmarks ranging from $\mathbf{5 0}$ to 80 percent.

\section{B. "Integrated Enterprise"}

Another standard utilizing the economic enterprise rather than the legal entity as the basis for statutory regulation is the "integrated enterprise" or "single employer" doctrine developed in American labor law by the National Labor Relations Board ${ }^{70}$ and upheld by the Supreme Court. ${ }^{71}$ Under the "integrated enterprise" standard,72 separate but closely related and "sufficiently integrated"73 concerns constitute a "single employer" for determination of certain issues arising under the National Labor Relations Act. ${ }^{74}$ In addition, the "integrated enterprise" standard also controls intragroup application of the American employment discrimination statutes - Title VII of the Civil Rights Act of $1964^{75}$ and The Age Discrimination in Employment Act. ${ }^{76}$

The "integrated enterprise" standard is functional, not conceptual. It looks to four factors throwing light on the degree of interrelationship of the affiliated corporations: (a) interrelation of operations; (b) centralized control of labor relations; (c) common management; (d) and common ownership or financial control.

\section{C. "Enterprise"}

Less significant examples of reliance on enterprise rather than entity in American statutory law may be found in the "enterprise" concepts utilized in the Fair Labor Standards Act" and the Racketeering Influenced and Corrupt Organizations Act."78 The Fair Labor Standards Act defines "enterprise" as

the related activities performed (either through unified operation or common control) by any person or persons for a common business purpose, and includes all such activities

68. E.g., 15 U.S.C. $\S 79 \mathrm{~b}(\mathrm{a})(7)$, (8), (11) (1982) (P·blic Utility Holding Company Act of 1935).

69. E.g., 15 U.S.C. $\S 80 a-2(a)(9)$ (1982) (Investment Company Act of 1940).

70. See 6 Fed. Reg. Empl. Serv. (Law. Co-op) $\$ \S 46: 8,46: 22$ (1978).

71. Radio \& Television Broadcast Technicians Local Union v. Broadcast Serv. of Mobile, Inc., 380 U.S. 255 (1965) (per curiam).

72. See P. Blumberg, The Law of Corporate Groups: General Statutory Law, supra note 12, at $\S 13.03 ; 6$ Fed. Reg. Empl. Serv. (Law. Co-op) $\S \S 45: 7,45: 93$ to $45: 94$ (1982).

73. See 21 NLRB Ann. Rep. 14 (1956).

74. 29 U.S.C. $\$ \S 151$ et seq. (1982).

75. 42 U.S.C. $\$ \S 2000$ e et seq. (1982).

76. 29 U.S.C. $\S 621$ et seq. (1982), as amended, 29 U.S.C. $\S 623($ h) (Supp. 1988).

77. 29 U.S.C. $\$ 203(\mathrm{r})(1982)$.

78. 18 U.S.C. $\S 1961$ et seq. (1982). 
whether performed in one or more establishments or by one or more corporate or other organizational units. ${ }^{79}$

\section{CONCLUSION}

The past discussion of the nature of the corporate personality in the United States has become doubly irrelevant. First, the commentaries have virtually ignored the modern development of corporate groups. As a result, the discussion rests on a stereotyped view of "the corporation" that with the passage of time no longer realistically describes the corporate world. Second, the discussion has been overwhelmingly concerned with an inquiry into the question of the rights to be accorded to the corporation, particularly rights of a corporation under the U.S. Constitution. These issues arose with greatest intensity a century ago in the days of vigorous economic development when recognition of corporate interests to promote economic growth had a special appeal. They have long since been almost entirely settled. Today, reflecting the dramatic change in the nature of corporate society, the crucial issue for heavily industrialized societies the world over, seeking to assure corporate responsibility and accountability, has become the reverse, the imposition of duties upon corporations, not the recognition of their rights.

In the face of modern economic development with its fundamental changes in corporate structure and operations, it has become necessary to undertake a fundamental reconsideration of entity law. Traditional views of the corporate personality in American law have become increasingly inadequate. The problems of a complex corporate system in the modern industrial age dominated by large multinational corporations with hundreds of thousands of public shareholders and corporate structures of "incredible complexity" 80 have outstripped traditional corporation law, shaped long ago under very different conditions.

Corporation law in the United States (and in other countries as well) is breaking down because of the increasing tension between conventional entity law deeming each corporation a separate juridical person, irrespective of its interrelationships with its affiliated corporations, and the economic reality of a complex industrial society predominantly conducted by corporate groups: parent companies, sub-holding companies, and scores or hundreds of subsidiary companies collectively conducting worldwide integrated enterprises. The predominance of such powerful multinational corporate complexes is creating irresistible pressures for the development of new legal concepts to impose more effective societal controls than those

79. 29 U.S.C. § $203(r)(1982)$.

80. See Hadden, "Inside Corporate Groups," 12 Int 7 J. Soc. L. 273, 274 (1984). 
available under traditional entity law reflecting the society of centuries ago. ${ }^{81}$

In light of such developments, it is no longer realistic to adhere to the traditional view that for legal purposes, each of the corporations in a corporate group is a separate legal entity with rights and duties unaffected by its functioning as a constituent of the group collectively conducting a common business under common control. It is time to consider whether the parent and affiliated companies of the group should also be liable in the particular case for the duties and obligations of the relevant subsidiary in order either to protect persons dealing with companies of the group in cases arising at common law or to implement governmental controls and prevent their frustration and evasion more effectively in cases involving statutory law. ${ }^{82}$

This requires a fundamental reconsideration of the traditional doctrines of entity law and the development of principles of enterprise law. Statutory law in the United States provides the most advanced examples of the response of the American legal system in dealing with this challenge. In various areas of the American common law, as well, some courts have made progress in pushing beyond the sterile confines of "piercing the veil jurisprudence" in the incipient formulation of enterprise law. Even in these early stages in the development of enterprise law, it is possible to discern a different theory of the corporate personality and an emerging law of corporate groups. This is a major problem of the legal order and urgently calls out for intensive scholarly examination and discussion.

81. See Wedderburn, "Multinationals and the Antiquities of Company Law," 47 Mod. L. Rev. 87, 90 (1984) (reviewing the "geriatric difficulties" of entity law in dealing with Multinational groups).

82. For a more extended discussion of the inadequacy of traditional theories of the corporate personality in a world economy dominated by multi-tiered multinational corporate groups, see Blumberg, "The Corporate Entity in an Era of Multinational Corporations," $15 \mathrm{Del}$. J. Corp. L. \#2 (1990). 
